\title{
COMPARATIVE STUDY OF DISCUSSION AND QUESTION-ANSWER LEARNING METHOD TO IMPROVE LEARNING OUTCOMES OF VOCATIONAL HIGH SCHOOL STUDENTS
}

\author{
Ira Pratiwi Ramdayana ${ }^{1}$, Hendro Prasetyono ${ }^{2}$, Nurul Viah Tsania Rahman ${ }^{3}$ \\ ${ }^{123}$ Universitas Indraprasta PGRI, Indonesia \\ 1irapratiwi413@yahoo.co.id, ${ }^{2}$ hendro_prasetyono@unindra.ac.id, ${ }^{3}$ nurul_viah23@yahoo.com
}

\begin{abstract}
This study aims to determine whether there are differences in learning outcomes using discussion learning methods and using the Q\&A learning method at Yaperjasa Vocational High School. The type of the research was Classroom Action Research with quantitative approach using the comparative method. The number of samples was 80 students which divided into 2 classes, namely class XI Office Administration 1 (control class) using the discussion method and class XI AP 2 (experimental class) using the question and answer method. The results of the study showed that there were 3 cycles, namely the first cycle $t$-value $>t$-table or $3.323>1.685$, in cycle II $t$-value $<t$-table and $-0.087<1.685$, and in cycle III $t$-value $>t$-table or 3.209> 1.685. Cycles I and III showed that t-value was greater than t-table. It meant that the values obtained by students in the control class with the experimental class there were significant differences in learning outcomes. Students' learning outcomes by applying discussion learning methods compared to using question and answer learning methods.
\end{abstract}

Keywords: discussion method, question and answer, comparative method, vocational high school

\section{STUDI KOMPARATIF METODE PEMBELAJARAN DISKUSI DAN TANYA JAWAB DALAM MENINGKATKAN HASIL BELAJAR SISWA SEKOLAH MENENGAH KEJURUAN}

\begin{abstract}
ABSTRAK
Penelitian ini bertujuan untuk mengetahui apakah ada perbedaan hasil belajar yang menggunakan metode pembelajaran diskusi dengan menggunakan metode pembelajaran Tanya jawab di Sekolah Menengah Kejuruan Yaperjasa. Jenis penelitian adalah Penelitian Tindakan Kelas dengan pendekatan penelitian adalah kuantitatif dengan metode komparatif. Jumlah sampel 80 peserta didik yang terbagi atas 2 kelas yaitu kelas XI Administrasi Perkantoran 1 (kelas kontrol) menggunakan metode diskusi dan kelas XI AP 2 (kelas eksperimen) menggunakan metode tanya jawab. Hasil penelitian terdapat 3 siklus, yaitu siklus I $t_{\text {hitung }}>t_{\text {tabel }}$ atau $3.323>1.685$, pada siklus II $t_{\text {hitung }}<t_{\text {tabel }}$ atau $-0.087<1.685$, dan pada siklus III $t_{\text {hitung }}>$

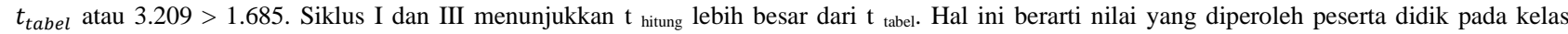
kontrol dengan kelas eksperimen terdapat perbedaan hasil belajar. Hasil belajar dengan penerapan metode pembelajaran diskusi lebih baik dalam meningkatkan hasil belajar peserta didik dibandingkan dengan menggunakan metode pembelajaran tanya jawab.
\end{abstract}

Kata Kunci: metode diskusi, tanya jawab, metode komparatif, penelitian tindakan kelas, sekolah menengah kejuruan

\begin{tabular}{|c|c|c|}
\hline Submitted & Accepted & Published \\
\hline 16 Maret 2020 & 10 April 2020 & 28 Mei 2020 \\
\hline
\end{tabular}

\begin{tabular}{|l|c|c|}
\hline Citation & $:$ & $\begin{array}{c}\text { Ramdayana, I.P., Prasetyono, H., \& Rahman, N.V.T. (2020). Comparative Study Of Discussion And Question-Answer } \\
\text { Learning Method To Improve Learning Outcomes Of Vocational High School Students. Jurnal PAJAR } \\
\text { (Pendidikan dan Pengajaran), 4(3), 597-607. DOI : http://dx.doi.org/10.33578/pjr.v4i2.7990. }\end{array}$ \\
\hline
\end{tabular}

\section{PENDAHULUAN}

Saat ini dunia berada pada kondisi yang serba tidak pasti dalam hal turbulansi ekonomi, politik dan lingkungan sosial sehingga membutuhkan sumberdaya manusia yang berkualitas (Anderson, 2017). Lembaga pendidikan memegang peranan penting dalam menghasilkan sumber daya manusia yang berkualitas (Saputra \& Prasetyono, 2020). Namun 
untuk mempersiapkan sumber daya yang berkualitas terutama sumber daya manusia yang tangguh, unggul dan kompeten saat ini menghadapi tantangan yang berat khususnya dalam dunia pendidikan. Lembaga pendidikan terutama pendidikan formal masih memegang peranan utama dalam menciptakan sumberdaya manusia yang unggul (Hendro Prasetyono, Abdillah, \& Fitria, 2018).

Salah satu jenis pendidikan formal saat ini yang sedang mendapat sorotan adalam Sekolah Menengah Kejuruan (SMK). Instruksi Presiden Nomor 9 Tahun 2016 tentang Revitalisasi Sekolah Menengah Kejuruan, yang disusul dengan nota kesepahaman antar kementerian terkait, seakan menjadi roket pendorong pendidikan vokasi di negeri ini (Kamdi, 2017). SMK merupakan lembaga pendidikan formal di bawah Direktorat Pembinaan SMK (DitpSMK) yang menyiapkan lulusannya untuk bekerja dengan bekal pengetahuan, keterampilan dan sikap kerja dalam bidang tertentu yang sesuai dengan kebutuhan Dunia Usaha dan Dunia Industri (DUDI), serta diharapkan dapat berwirausaha (Indriaturrahmi \& Sudiyatno, 2016). Berkualitas atau tidaknya lulusan SMK dapat dilihat salah satu indikatornya dari keterserapan lulusan dalam Dunia Usaha/Dunia Industri (Du/Di). Data keterserapan dan jumlah pengangguran lulusan SMK terlihat dari data BPS yang tersaji pada tabel berikut:

Tabel 1. Jumlah lulusan SMK yang terserap pada Du/Di dan persentase pengangguran

\begin{tabular}{ccc}
\hline Tahun & Terserap di DU/DI & Pengangguran lulusan SMK (\%) \\
\hline 2016 & 12.1 juta & $9.84 \%$ \\
2017 & 12.5 juta & $9.27 \%$ \\
2018 & 13.6 juta & $8.92 \%$ \\
2019 & 13.8 Juta & $8.32 \%$ \\
\hline
\end{tabular}

Sumber : Sakernas dan BPS Kemendibud, 2019

Berdasarkan tabel tersebut terlihat bahwa jumlah lulusan SMK yang terserap dalam dunia kerja cukup tinggi dan jumlah pengangguran dari lulusan SMK telah menunjukkan penurunan setiap tahunnya, namun angka tersebut masih tetap tinggi. Oleh karena itu perlu dilakukan upaya-upaya lain untuk terus meningkatkan jumlah keterserapan lulusan SMK sehingga menurunkan angka pengangguran. Salah satu ciri sumberdaya manusia yang berkualitas ditentukan oleh hasil belajar yang didapat saat menempuh jenjang pendidikan formal (Nurfarhana, Abdillah, \& Prasetyono, 2017). Hasil belajar menyajikan hasil evaluasi pembelajaran dari aspek kognitif, afektif dan psikomotorik. Hasil belajar sendiri merupakan kemampuan dan tingkat pemahaman yang diperoleh peserta didik melalui kegiatan belajar yang sudah dilaksanakan oleh pendidik (İlic \& Akbulut, 2019). Salah satu faktor yang menentukan hasil belajar peserta didik dari aspek eksternal adalah metode pembelajaran yang dipraktekkan oleh guru di sekolah (Slameto, 2010:54)

Metode pembelajaran yang digunakan oleh pendidik saat mengajar mempengaruhi tingkat keberhasilan belajar peserta didik dalam belajar (Lutvaidah, 2016). Saat ini telah banyak literatur yang telah mengulas metode pembelajaran jigsaw, kooperatif, demontrasi (Prananingrum, 2017; Jasmini, 2019) namun belum banyak literatur yang mengulas tentang metode pembelajaran diskusi dan tanya jawab. Padahal metode diskusi dan tanya jawab merupakan metode yang paling banyak digunakan oleh guru Indonesia dalam mengajar selain metode ceramah (Jasmini, 2019).

Metode pembelajaran memiliki pemahaman yakni cara yang digunakan untuk mengimplementasikan rencana yang sudah disusun dalam kegiatan nyata agar tujuan yang telah disusun tercapai secara optimal. Dengan demikian, metode dalam rangkaian sistem pembelajaran memegang peran yang sangat penting. Keberhasilan implementasi strategi pembelajaran sangat tergantung pada cara pendidik menggunakan metode pembelajaran, karena suatu strategi pembelajaran hanya mungkin dapat diimplementasikan melalui penggunaan metode pembelajaran (Yibeltal \& Tessega, 2020). Indikator keberhasilan dalam belajar memiliki 
tujuan untuk peserta didik agar dapat menjelaskan hakikat mengeluarkan pendapat, menganalisis akibat pembatasan mengeluarkan pendapat, menganalisis konsekuensi mengeluarkan pendapat tanpa batas atau tidak bertanggung jawab, serta mendemontrasikan cara mengeluarkan pendapat yang dilakukan secara benar dan bertanggung jawab (Loyko, Dryga, Park, \& Palianov, 2015).

Penggunaan metode diskusi dalam kegiatan pembelajaran dimaksudkan untuk mengembangkan keberanian peserta didik dalam mengemukakan pendapatnya sendiri dan mencari pemecahan solusi masalah dengan pertimbangan dari pendapat orang lain (Raden Rizky Amaliah, Abdul Fadhil, 2014). Metode diskusi perlu diterapkan dalam proses pembelajaran untuk menyiapkan peserta didik agar tidak canggung ketika kembali ke masyarakat dimana dibutuhkan keahlian dan kemampuan untuk menyelesaikan masalah bersama-sama. Peserta didik juga dapat memperluas pengetahuannya dengan adanya pendapat orang lain sehingga dapat menumbuhkan rasa ingin tahu peserta didik dalam pemecahan masalah yang sedang diperdebatkan dan akan adanya kerjasama kelompok yang baik dapat meningkatkan rasa percaya diri peserta didik satu sama lain.

Metode tanya jawab merupakan metode yang digunakan dengan memberikan materi yang akan dibahas dan kemudian memberikan kesempatan bagi peserta didik untuk bertanya dan peserta didik lain dapat menjawab pertanyaan yang diajukan temannya. Namun, apabila yang disampaikan masih kurang sempurna maka pendidik akan meluruskan maksud dan tujuan dari jawaban peserta didik tersebut. Metode pembelajaran tanya jawab mengarah kepada

\section{KAJIAN TEORETIS}

\section{Hasil Belajar}

Menurut Hamalik (2008:103) "hasil belajar adalah sebagai terjadinya perubahan tingkah laku pada diri seseorang yang dapat diamati dan diukur bentuk pengetahuan, sikap, dan keterampilan. Perubahan tersebut dapat diartikan sebagai terjadinya peningkatan dan pengembangan yang lebih baik sebelumnya yang tidak tahu tersampaikannya isi pelajaran kepada peserta didik secara langsung dan meningkatkan kemauan peserta didik untuk berani bertanya maupun menjawab. Hal ini dapat meningkatkan keberanian peserta didik untuk berbicara dan kepercayaan dirinya karena saat bertanya atau menjawab disaksikan dan didengar oleh rekan-rekan di kelas. Metode diskusi dan metode tanya jawab yang menekankan kepada proses penyampaian materi secara verbal dari seorang pendidik kepada peserta didik dengan maksud agar peserta didik dapat menguasai materi pemelajaran secara optimal. Metode ini juga dapat dikatakan sebagai metode pembelajaran langsung yang berhubungan dengan tingkat pengetahuan serta keaktifan peserta didik yang saling berkomunikasi dan berinteraksi dalam memahami kasus ataupun materi pelajaran yang disampaikan.

Fenomena yang menarik penulis temukan di SMK Yapan adalah para guru pengajar Mata Pelajaran Kewirausahaan dalam mengajar menggunakan metode ceramah dan memotivasi peserta didik namun sering pula pendidik hanya meminta peserta didik untuk mengerjakan LKS. Hal ini dirasakan masih perlu ditingkatkan agar peserta didik memahami materi yang disampaikan oleh pendidik. Sehingga penulis tertarik untuk mengadakan studi komparatif yaitu dengan membandingkan pembelajaran prakarya dan kewirausahaan yang menggunakan metode pembelajaran diskusi dan metode pembelajaran tanya jawab. Dengan harapan dapat memberikan solusi kepada pendidik mata pelajaran Prakarya dan kewirausahaan untuk menemukan cara atau metode yang tepat dalam meningkatkan hasil belajar Mata Pelajaran Prakarya dan Kewirausahaan kelas XI.

menjadi tahu". Sedangkan menurut Purwanto (2011:46) menyatakan bahwa "hasil belajar adalah perubahan perilaku peserta didik akibat belajar. Perubahan perilaku disebabkan karena peserta didik mencapai penguasaan atas sejumlah bahan yang diberikan dalam proses belajar mengajar. Lebih lanjut lagi bahwa ia mengatakan hasil 
belajar dapat berupa perubahan dalam aspek kognitif, afektif dan psikomotorik".

Rifa'i dan Chatarina (2009:97)

berpendapat bahwa "faktor-faktor yang memberikan kontribusi terhadap proses dan hasil belajar adalah kondisi internal dan eksternal peserta didik. Kondisi internal mencakup kondisi fisik, seperti kesehatan organ tubuh, kondisi psikis seperti kemampuan intelektual, emosional, dan kondisi sosial, seperti kemampuan bersosialisasi dengan lingkungan. Sama kompleksnya pada kondisi internal adalah kondisi eksternal yang ada di lingkungan peserta didik. Beberapa faktor eksternal seperti variasi dan tingkat kesulitan materi belajar (stimulus) yang dipelajari (direspon), tempat belajar, iklim, suasana lingkungan, dan budaya belajar masyarakat akan mempengaruhi kesiapan, proses, dan metode pembelajaran.

\section{Metode Pembelajaran Diskusi dan Tanya Jawab}

Metode pembelajaran adalah cara yang digunakan pendidik dalam mengadakan hubungan dengan peserta didik pada saat berlangsung pembelajaran". Sudjana dalam (Aqib dan Murtadlo, 2016:10). Sedangkan menurut Syaiful Sagala dalam Raden Rizky Amaliah dan Abdul Fadhil (2014) metode diskusi adalah percakapan ilmiah yang responsif berisikan pertukaran pendapat yang dijalin dengan pertannyaanpertannyaan problematis, pemunculan ide-ide dan pengujian ide-ide ataupun pendapat, dilakukan oleh beberapa orang yang tergabung dalam kelompok itu yang diarahkan untuk memperoleh pemecahan masalahnya dan untuk mencari kebenaran.

Menurut Sutriani dalam (Aqib dan Murtadlo, 2016:64) metode diskusi dalam pembelajaran terdiri atas berbagai macam bentuk diskusi, diantaranya sebagai berikut: (a) Whole Group, merupakan bentuk diskusi kelompok besar (pleno, klasikal, paripurna, dan lain-lain); (b) Buzz Group, merupakan suatu diskusi kelompok kecil yang terdiri atas 3-6 orang. Tempat duduk diatur sedemikan rupa sehingga peserta didik saling berhadapan untuk memudahkan pertukaran pendapat; (c) Panel, merupakan diskusi kelompok kecil (3-6 orang) yang dianggap ahli untuk mendiskusikan objek tertentu dengan cara duduk melingkar yang dipimpin oleh moderator; (d) Syndicate Group, merupakan bentuk diskusi dengan cara membagi kelas menjadi beberapa kelompok kecil yang terdiri dari 3-6 orang yang masing-masing melakukan tugas-tugas yang berbeda;(e) Simposium, merupakan bentuk diskusi yang dilaksanakan dengan membahas berbagai aspek dengan subjek tertentu, dalam kegiatan ini sering menggunakan sidang paralel karena ada beberapa orang penyaji setiap penyaji mempersentasikan karyanya dalam waktu 5-20 menit diikuti dengan sanggahan dirumuskan oleh panitia sebagai hasil simposium; (f) Brainstorming, merupakan suatu diskusi dimana anggota kelompok bebas menyumbangkan ide-ide baru terhadap suatu masalah tertentu, di bawah pimpinan seorang ketua dan diselesaikan dengan cepat (waktu pendek); (g) Informal Debate, merupakan diskusi dengan cara membagi kelas menjadi dua kelompok yang pro dan kontra yang dalam diskusi ini diikuti dengan tangkisan dengan tata tertib yang longgar agar diperoleh kajian yang dimensi dan kedalamannnya tinggi; (h) Seminar, pada umumnya merupakan suatu pembahasan yang bersifat ilmiah dengan membahas suatu topik terbaru; (i) Colloqinin, merupakan suatu kegiatan dimana peserta didik dihadapkan pada narasumber mengajukan pertanyaan; (j) First Rowt. Diskusi terdiri atas beberapa orang peserta yang dipimpin oleh seorang ketua. Tempat duduk diatur setengah lingkaran dengan dua atau tiga kursi kosong menghadap peserta, seolah-olah menjaring ikan dalam sebuah mangkuk.

Menurut Djajadisastra dalam Suryasubroto (2009:170) Langkah-langkah dalam implementasi metode diskusi yang efektif adalah sebagai berikut: mengemukakan saran mengenai usaha-usaha yang dapat dilakukan sebagai berikut: (1) Peserta didik dikelompokkan menjadi kelompok-kelompok kecil, misalnya lima orang murid setiap kelompokkelompok kecil ini harus terdiri dari murid-murid yang pandai dan kurang pandai, yang pandai bicara dan kurang pandai berbicara, peserta didik laki-laki dan perempuan. Hal ini harus diatur benar-benar dapat bekerja sama. Dalam setiap kelompok ditetapka ketuanya; (2) Agar tidak menimbulkan 
rasa "kelompok-isme" ada baiknya bila untuk setiap diskusi dengan topik atau problema baru selalu dibentuk lagi kelompok-kelompom baru dengan cara melakukan pertukaran anggotaanggota kelompok. Dengan demikian semua peserta didik akan pernah mengalami suasana bekerjasama dalam satu kelompok dan juga pernah mengalami bekerjasama dengan semua teman sekelasnya; (3) Topik-topik atau masalah yang akan dijadikan pokok-pokok diskusi dapat diambil dari buku-buku pelajaran peserta didik, dari suratsurat kabar, dari kejadian sehari-hari disekitar sekolah, dan kegiatan di masyarakat yang sedang menjadi pusat perhatian penduduk setempat; (4) Mengusahakan penyesuaian waktu dengan berat topik yang dijadikan pokok diskusi. Membagi-bagi diskusi didalam beberapa hari atau minggu berdasarkan pembagian topik ke dalam topik-topik yang lebih kecil lagi (sub topik). Keleluasaan berdiskusi dapat pula dilakukan dengan menyelenggarakan suatu pekan diskusi dimana seluruh pekan itu dipergunakan untuk mendiskusikan problema-problema yang telah dipersiapkan sebelumnya; (5) Menyiapkan dan melengkapi semua sumber data yang diperlukan, baik yang tersedia di sekolah maupun yang terdapat di luar sekolah.

Metode tanya jawab adalah cara penyajian pelajaran dalam bentuk pertanyaan yang harus dijawab, terutama dari pendidik kepada peserta didik, tetapi dapat pula dari peserta didik kepada pendidik (Slameto, 2010). Senada dengan pengertian ini, Istarani dalam Aqib dan Murtadlo (2016:203) mengemukakan pendapat bahwa "metode tanya jawab adalah suatu cara yang ditempuh oleh pendidik dalam rangka

\section{METODE PENELITIAN}

Jenis Penelitian yang digunakan yakni PTK (Penelitian Tindakan Kelas). Menurut Homkins dalam Muslich (2010:8) menyatakan bahwa "PTK adalah suatu bentuk kajian yang bersifat reflektif, yang dilakukan oleh pelaku tindakan untuk mengingatkan kemantapan rasional dari tindakan-tindakannya dalam melaksanakan tugas dan memperdalam pemahaman terhadap kondisi dalam praktik pembelajaran". pembelajaran yang bersifat aktif individual dengan mengakibatkan terjadinya komunikasi secara langsung yang bersifat two way traffic antara pendiik dan pendidik, atau antarsesama peserta didik, atau antara peserta didik dan penidik". Sementara itu, Aqib dan Murtadlo (2016:203) dinyatakan bahwa "metode tanya jawab adalah suatu cara penyajian pelajaran dalam bentuk pertanyaan yang harus dijawab, terutama dari pendidik kepada peserta didik.

Beberapa hal yang perlu diperhatikan dalam penggunaan metode tanya jawab menurut Depdikbud dalam Aqib dan Murtadlo (2016:205), yaitu (1) Materi menarik dan menentang serta nilai aplikasi tinggi; (2) Pertanyaan bervariasi, meliputi pertanyaan tertutup (pertanyaan yang jawabannya hanya satu kemungkinan) dan pertanyaan terbuka (pertanyaan dengan banyak kemungkinan jawaban); (3) Jawaban pertanyaan itu diperoleh dari penyempurnaan jawaban-jawaban peserta didik; (4) Dilakukan dengan teknik bertanya yang baik.

Menurut Mulyana dalam Aqib dan Murtadlo (2016:205) Untuk menghindari penyimpangan dari pokok persoalan materi yang sedang dibahas, penggunaan metode tanya jawab harus memerhatikan langkah-langkah sebagai berikut (1) Merumuskan tujuan tanya jawab sejelas-jelasnya dalam bentuk tujuan khusus dan berpusat pada tinglah laku pesertta didik; (2) Mencari alasan pemilihan metode tanya jawab; (3) Menetapkan kemungkinan pertanyaan yang akan dikemukakan; (4) Menetapkan kemungkinan jawaban untuuk menjaga agar tidak menyimpang dari pokok persoalan; (5) Menyediakan kesempatan bertanya bagi peserta didik.

Dari penjelasaan di atas, maka dalam penelitian ini peneliti menggunakan metode penelitian komparatif, pendekatan kuantitatif dan penelitian PTK jenis partisipan dimana peneliti terlibat langsung dalam proses penelitian sejak awal sampai dengan hasil penelitian berupa laporan (Ananda, Rafida, \& Syahrum, 2014). Penelitian komparatif ini bertujuan untuk menemukan persamaan dan perbedaan antara dua 
variabel yang berbeda dan menemukan salah satu variabel yang lebih efektif digunakan (Fitria, Abdillah, Prasetyono, \& Cahyo, 2019). Tujuan penelitian PTK adalah untuk mengetahui secara langsung perubahan terhadap hasil belajar yang dilaksakan di kelas dengan metode pembelajaran yang berbeda (Subadi, 2010). Eksperimen yang dilakukan sebanyak 3 kali yang dinamai dengan siklus.

Populasi targetnya yaitu seluruh peserta didik SMK YAPERJASA yang berjumlah 501 peserta didik, sedangkan yang menjadi populasi terjangkau yaitu peserta didik kelas XI SMK YAPERJASA yang berjumlah 160 peserta didik. Pada penelitian ini di ambil dua kelas sebagai sampel yaitu peserta didik kelas XI AP 1 dengan jumlah 40 peserta didik sebagai kelas kontrol dan kelas XI AP 2 dengan jumlah 40 peserta didik sebagai kelas eksperimen. Maka dapat dilihat bahwa sampel penelitian ini berjumlah 80 peserta didik dengan teknik sampel purposive sampling. Teknik pengambilan sampel dengan purposive sampling karena peneliti memiliki pertimbangan dalam pemilihan sampel untuk kelas $\mathrm{X}$ yang masih baru menempuh jenjang SMK (Arikunto, 2006:145). Peneliti dalam memperoleh data menggunaan posttest dengan 10 butir soal pilihan ganda, dan 5 butir soal uraian pada masing-masing bab pembahasan dengan kisi-kisi soal tes sebagai berikut:

Tabel 2. Kisi-kisi Soal Tes

\begin{tabular}{|c|c|c|}
\hline Materi pokok & Indikator & Nomor \\
\hline $\begin{array}{l}\text { Produk kerajinan dari } \\
\text { bahan lunak dan } \\
\text { pengemasannya }\end{array}$ & $\begin{aligned} & \text { Mendeskripsikan perkembangan seni kriya Indonesia } \\
& \text { Mengidentifikasidan mendeskripsikan teknik pembuatan keramik } \\
& \text { dengan teknik pilin } \\
& \text { Mendeskripsikan jenis-jenis seni keramik Indonesia dan bahan } \\
& \text { pembuatannya } \\
> & \text { Mendeskripsikan pengertian dekorasi keramik } \\
> & \text { Mendeskripsikan bahan apa saja yang dapat digunakan untuk dekorasi } \\
& \text { keramik }\end{aligned}$ & $\begin{array}{l}10,11 \\
12,13 \\
14,15\end{array}$ \\
\hline $\begin{array}{l}\text { Desain produk dan } \\
\text { pengemasan } \\
\text { pengolahan dari } \\
\text { bahan nabati dan } \\
\text { hewani menjadi } \\
\text { makanan khas daerah } \\
\text { setempat }\end{array}$ & $\begin{aligned} & \text { Mendeskripsikan ruang lingkup pengolahan bahan pangan } \\
& \text { Mengidentifikasi dan mendeskripsikan pengolahan bahan nabati dan } \\
& \text { hewani menjadi makanan khas daerah } \\
& \text { Mendeskripsikan di bidang makanan khas daerah dari bahan nabati dan } \\
& \text { hewani } \\
> & \text { Mengidentifikasi terhadap makanan khas daerah sebagai produk dari } \\
& \text { hasil pengolahan bahan nabati dan hewani }\end{aligned}$ & $\begin{array}{c}1,2,3,4,5 \\
6,7,8 \\
9,10,11 \\
12 \\
13,14 \\
15\end{array}$ \\
\hline $\begin{array}{l}\text { Desain produk dan } \\
\text { pengemasan } \\
\text { pengolahan dari } \\
\text { bahan pangan nabati } \\
\text { dan hewani menjadi } \\
\text { produk kosmetik }\end{array}$ & $\begin{aligned} & \text { Mendeskripsikan kosmetik dari bahan nabati } \\
& \text { Mengidentifikasi dan mendeskripsikan pengolahan bahan nabati dan } \\
& \text { hewani menjadi kosmetik } \\
& \text { Mendeskripsikan teknik pembuatan kosmetik dari bahan nabati dan } \\
& \text { hewani } \\
> & \text { Mendeskripsikan kewirausahaan di bidang kosmetik dari bahan nabati } \\
& \text { dan hewani }\end{aligned}$ & $\begin{array}{c}1,2,3 \\
4,5,6,7 \\
8,9,10 \\
11,12 \\
13,14 \\
15\end{array}$ \\
\hline Total & & 45 \\
\hline
\end{tabular}

Sumber: Diolah dari Buku Prakarya dan Kewirausahaan (Yulianto,dkk., 2014) 
Kisi-kisi soal tes tersebut kemudian disusun menjadi 45 butir pertanyaan kemudian diuji tingkat kesukaran dan daya pembeda. Hasilnya menunjukkan uji tingkat kesukaran

\section{HASIL DAN PEMBAHASAN}

Penelitian dilaksanakan dengan 3 siklus. Setiap siklus diawali dengan mengajar di kelas AP 1 dengan metode diskusi dan kelas AP 2 dengan berada pada kategori sedang, daya pembedan baik. Analisis data menggunakan analisis deskriptif dan uji hipotesis menggunakan uji t.

Tabel 3. Data Perbandingan Statistik Deskriptif PTK

\begin{tabular}{lcccccc}
\hline \multirow{2}{*}{$\begin{array}{c}\text { Hasil Belajar } \\
\text { Prakarya dan } \\
\text { Kewirausahaan }\end{array}$} & \multicolumn{2}{c}{ SIKLUS I } & \multicolumn{2}{c}{ SIKLUS II } & \multicolumn{2}{c}{ SIKLUS III } \\
\cline { 2 - 7 } & Eksperimen & Kontrol & Ekperimen & Kontrol & Eksperimen & Kontrol \\
\hline Nilai Terendah & 41 & 29 & 35 & 35 & 35 & 36 \\
Nilai Tertinggi & 100 & 100 & 99 & 100 & 100 & 100 \\
Jumlah & 3238.5 & 2677.5 & 2714 & 2730 & 2844 & 2316 \\
Mean & 80.9625 & 66.9375 & 67.85 & 68.25 & 71.1 & 57.9 \\
Median & 77.045 & 76.5 & 69.5 & 66.9 & 72.5 & 53.357 \\
Modus & 79.92 & 32.1 & 42.5 & 67.9 & 61.227 & 54.2 \\
Varians & 214.9 & 498.04 & 429.21 & 417.58 & 387.32 & 289.48 \\
Simpangan Baku & 14.6595 & 22.3168 & 20.72 & 20.4 & 19.433 & 17.014 \\
(S) & & & & & &
\end{tabular}

Sumber: diolah dari penelitian ini

Berdasarkan tabel tersebut diketahui nilai tertinggi terdapat pada siklus 1 dan 3 sedangkan nilai terendah baik pada kelas kontrol maupun eksperimen berada pada siklus 2. Jumlah tertinggi berada di kelas eksperimen pada siklus 1 dan jumlah terendah pada pada kelas kontrol pada siklus 3. Nilai tengah tertinggi berada pada siklus 1 di kelas eksperimen dan jumlah terendah berada pada siklus 3 di kelas kontrol. Nilai simpangan baku tertinggi berada di siklus 2 baik pada kelas eksperimen dan kelas kontrol. Hal ini berarti data yang dihasilkan merupakan data normal dengan persebaran yang merata.

Analisis selanjutnya dilanjutkan dengan uji hipotesis. Hasil uji hipotesis Siklus I adalah sebagai berikut:

$$
\begin{aligned}
t \quad & =\frac{\bar{X}_{1}-\bar{X}_{2}}{\sqrt{\frac{S_{1}^{2}}{n_{1}}+\frac{S_{2}^{2}}{n_{2}}}} \\
& =\frac{80,96-66,9375}{\sqrt{\frac{214,9}{40}}+\frac{498,04}{40}} \\
& =\frac{14,025}{4,2217}=3,323
\end{aligned}
$$

Maka uji hipotesis yang diperoleh

$\mathrm{H}_{0}: \mu_{1}=\mu_{2}$

$\mathrm{H}_{\mathrm{a}}: \mu_{1}>\mu_{2}$ 


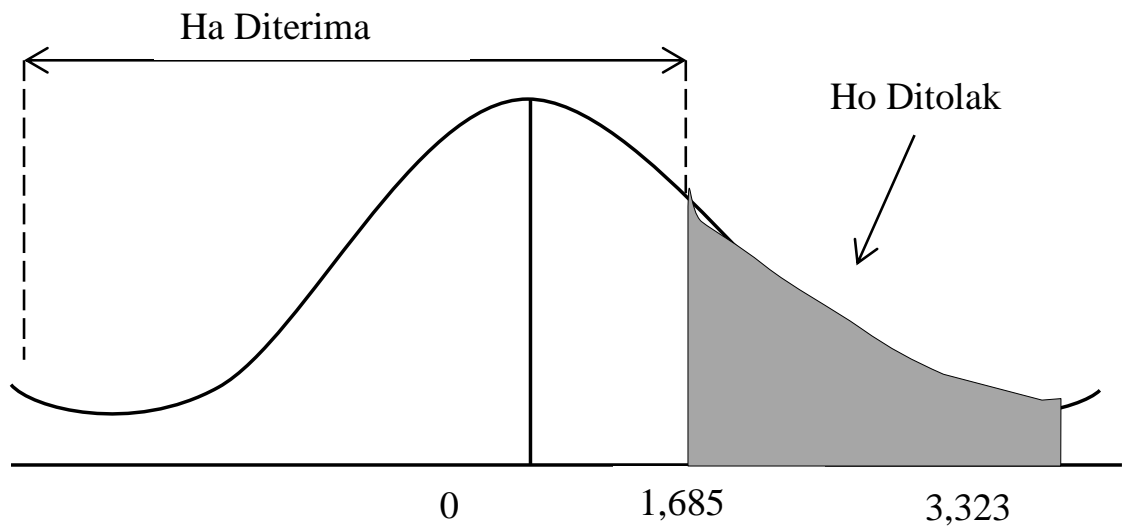

Gambar 1. Kurva Penelitian siklus I

Pada uji t, dimana $t_{\text {hitung }}$ lebih besar dari $t_{\text {tabel }}$ maka Ha diterima dan Ho ditolak. Gambar 4.3 juga menjelaskan bahwa $t_{\text {hitung }}$ jatuh pada daerah penolakan Ho, sehingga Ha diterima. Jadi kesimpulannya adalah $t_{\text {hitung }}$ sebesar $3.323>$ dari $t_{\text {tabel }}$ sebesar 1.685 maka Ha diterima dimana terdapat pengaruh metode pembelajaran diskusi terhadap hasil belajar peserta didik.

Hasil uji hipotesis siklus II sebagai berikut:

$$
\begin{aligned}
t \quad & =\frac{\bar{X}_{1}-\bar{X}_{2}}{\sqrt{\frac{S_{1}^{2}}{n_{1}}}+\frac{S_{2}^{2}}{n_{2}}} \\
& =\frac{67,85-68,25}{\sqrt{\frac{429,21}{40}+\frac{417,58}{40}}} \\
& =\frac{-0,4}{4,6}=-0,087
\end{aligned}
$$

Maka uji hipotesis yang diperoleh

$\mathrm{H}_{0}: \mu_{1=\mu_{2}}$

$\mathrm{H}_{\mathrm{a}}: \mu_{1}<\mu_{2}$

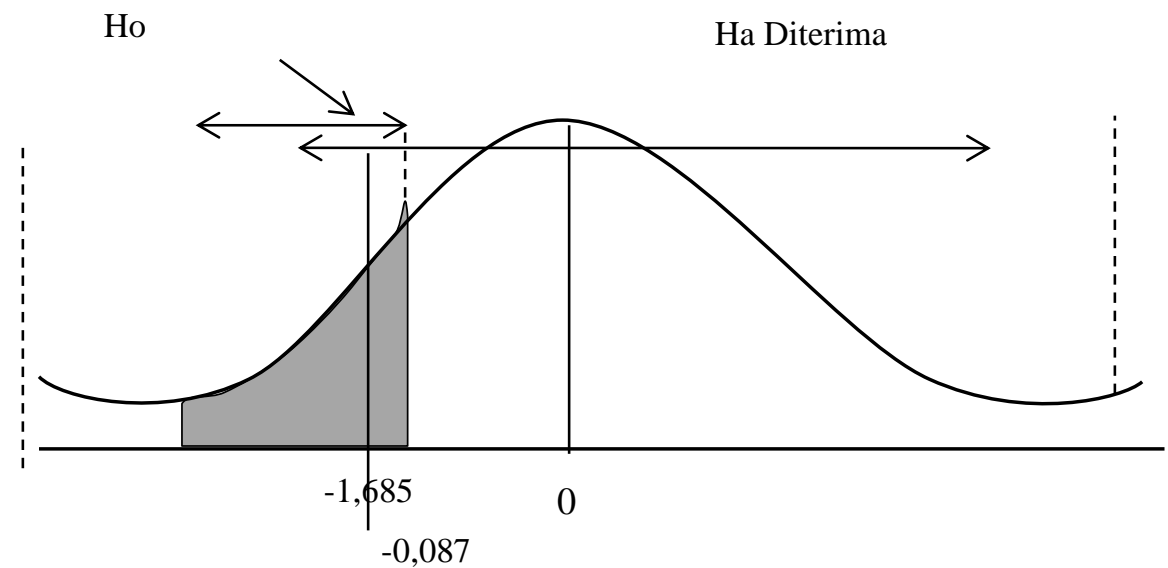

Gambar 2. Kurva Penelitian siklus II 
Pada uji t, dimana $t_{\text {hitung }}$ lebih kecil dari $t_{\text {tabel }}$ maka Ha ditolak dan Ho diterima. Gambar 4.4 juga menjelaskan bahwa $t_{\text {tabel }}$ jatuh pada daerah penolakan Ha, sehingga Ho dtetrima. Jadi kesimpulannya adalah $t_{\text {hitung }}$ sebesar $-0.087<$ dari $t_{\text {tabel }}$ sebesar 1.685 maka Ha diterima dimana tidak terdapat pengaruh metode pembelajaran diskusi terhadap hasil belajar peserta didik. berikut:

$$
\begin{aligned}
t \quad & =\frac{\bar{X}_{1}-\bar{X}_{2}}{\sqrt{\frac{S_{1}^{2}}{n_{1}}}+\frac{S_{2}^{2}}{n_{2}}} \\
& =\frac{71,1-57,9}{\sqrt{\frac{387,32}{40}}+\frac{289,48}{40}} \\
& =\frac{13,2}{4,1133}=3,209
\end{aligned}
$$

Maka uji hipotesis yang diperoleh

$\mathrm{H}_{0}: \mu_{1}=\mu_{2}$

$\mathrm{H}_{\mathrm{a}}: \mu_{1}>\mu_{2}$

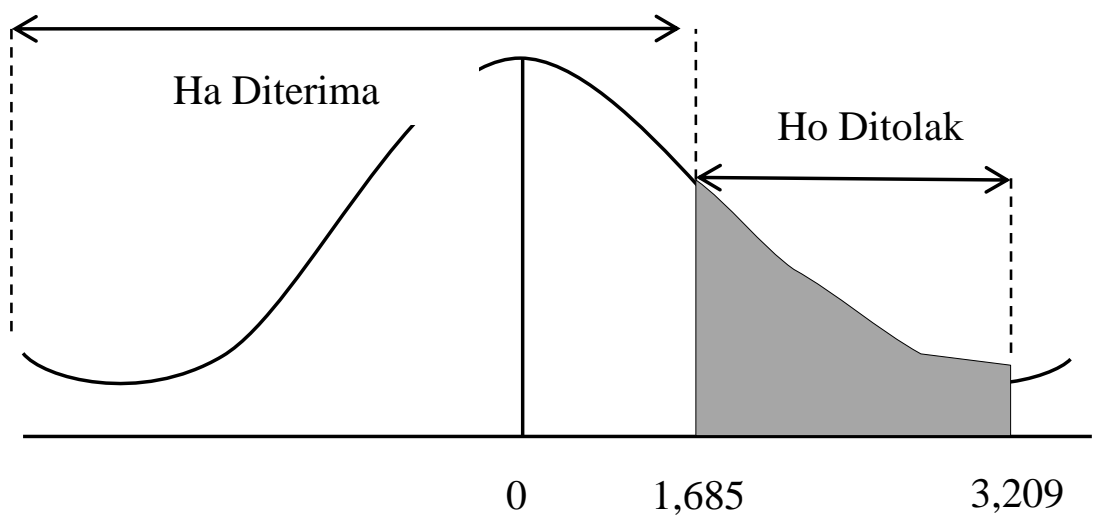

Gambar 3. Kurva Penelitian siklus III

Pada uji t, dimana $t_{\text {hitung }}$ lebih besar dari $t_{\text {tabel }}$ maka Ha diterima dan Ho ditolak. Gambar 4.3 juga menjelaskan bahwa $t_{\text {hitung }}$ jatuh pada daerah penolakan Ho, sehingga Ha diterima. Jadi kesimpulannya adalah $t_{\text {hitung }}$ sebesar $3.209>$ darit $_{\text {tabel }}$ sebesar 1.685 maka Ha diterima dimana terdapat pengaruh metode pembelajaran diskusi terhadap hasil belajar peserta didik. Dengan demikian dilihat dari dua siklus bahwa pada siklus I $t_{\text {hitung }} 3.323>t_{\text {tabel }} 1.685$ maka $H_{i}$ diterima dan pada siklus III $t_{\text {hitung }} 3.209>t_{\text {tabel }}$ 1.685 maka $H_{i}$ diterima. Hal ini berarti hasil belajar prakarya dan kewirausahaan lebih tinggi hasil belajarnya dengan menggunakan metode pembelajaran diskusi dibandingkan dengan metodepembelajaran tanya jawab.

Dari hasil penelitian yang penulis lakukan dapat diketahui hasil uji hipotesis statistik satu pihak yaitu Ho : $\mathrm{p}=0$ dan $H_{i}: \mathrm{p} \neq 0$ dengan tingkat signifikan sebesar $5 \%$ dah hasil $t_{\text {hitung }}$ pada siklus $\mathrm{I}=3.323$ dan siklus II $=3.209$. Kemudian membandingkan dengan $t_{\text {tabel }}$ dengan mencari $\mathrm{dk} / \mathrm{df}$ menggunakan rumus $\mathrm{n}-1=40-1=39$, maka dapat diketahui $\mathrm{dk} / \mathrm{df}$ yaitu 39 dan $t_{\text {tabel }}$ $=(0.05 ; 39)=1.685$. Dengan perhitungan uji hipotesis diketahui bahwa $t_{\text {hitung }}>t_{\text {tabel }}$ pada siklus I (3.323 > 1.685 pada tingkat signifikan sebesar $0.05=5 \%)$ pada siklus II $(3.209>1.685$ pada tingkat signifikan sebesar $0.05=5 \%$ ) dan mencari $\mathrm{dk} / \mathrm{df}$ dengan rumus $\mathrm{n}-1=40-1=39$, maka dapat diketahui $\mathrm{dk} / \mathrm{df}$ yaitu 39 dari $t_{\text {tabel }}=$ $(0.05 ; 39)=1.685$.

Hasil ini serupa dengan sebelumnya yang menyatakan hasil belajar dengan menggunakan metode diskusi lebih tinggi dibandingkan dengan penggunaan metode tanya jawab (Iim Inayah \& Khoiri, 2013; Jasmini, 2019; Prananingrum, 2017; Raden Rizky Amaliah, Abdul Fadhil, 2014). Penggunaan metode diskusi lebih tinggi hasilnya 
dapat disebabkan karena ketika belajar dengan diskusi persepsi siswa adalah belajar dengan rekan sebaya sehingga lebih nyaman dan gur tetap menjadi fasilitator serta pembimbing di kelas (Gerritsen-van Leeuwenkamp, Joosten-ten Brinke, \& Kester, 2019). Pembelajaran yang melibatkan rekan sebaya atau rekan di kelas juga akan lebih

\section{SIMPULAN DAN REKOMENDASI}

Berdasarkan pembahasan 3 siklus eksperimen tersebut maka dapat disimpulkan bahwa metode pembelajaan yang digunakan oleh pendidik mempengaruhi hasil belajar siswa. Metode pembelajaran dengan menggunakan diskusi lebih baik dibandingkan dengan metode belajar tanya jawab dalam penelitian ini. Para guru

\section{DAFTAR PUSTAKA}

Ananda, R., Rafida, T., \& Syahrum. (2014). Penelitian Tindakan Kelas. https://doi.org/10.21831/jpai.v6i1.1793

Fitria, D., Abdillah, A., Prasetyono, H., \& Cahyo, I. D. (2019). The Difference of Enterprises Taxpayers Compliance after Tax Amnesty. Journal of Economics and Policy, 12(1), 86-99.

https://doi.org/https://doi.org/10.15294/jejak .v12i1.18826

Gerritsen-van Leeuwenkamp, K. J., Joosten-ten Brinke, D., \& Kester, L. (2019). Students' perceptions of assessment quality related to their learning approaches and learning outcomes. Studies in Educational Evaluation, $\quad 63, \quad 72-82$. https://doi.org/10.1016/j.stueduc.2019.07.00 5

Iim, I., \& Khoiri, N. (2013). Studi Komparasi Model Pembelajaran Two Stay Two Stray Dengan Metode Diskusi Dan Model Direct Intruction Dengan Metode Resitasi Berbantuan Buku Saku Terhadap Aktivitas Dan Hasil Belajar Kognitif Siswa. Jurnal Penelitian Pembelajaran Fisika, 4(9), 1-5. https://doi.org/10.1017/CBO978110741532 $\underline{4.004}$ efektif karena siswa akan lebih mudah dan nyaman untuk mengemukakan pendapatnya (Lutvaidah, 2016). Selain itu dapat meningkatkan karakter siswa karena ketika berbicara di depan rekan-rekan di kelas harus jujur dan informasi yang disampaikan benar adanya ( $\mathrm{H}$. Prasetyono, Abdillah, Widiarto, \& Sriyono, 2018).

sebaiknya menggunakan metode pembelajaran diskusi dibandingkan dengan penggunaan metode pembelajaran konvensional lainnya. Namun dalam penggunaan metode diskusi tetap harus melakukan bimbingan dan pengajar agar diskusi yang dilaksanakan di kelas tidak keluar dari ketentuan.

İlic, U., \& Akbulut, Y. (2019). Effect of disfluency on learning outcomes, metacognitive judgments and cognitive load in computer assisted learning environments. Computers in Human Behavior, 99, 310-321. https://doi.org/10.1016/j.chb.2019.06.001

Indriaturrahmi, \& Sudiyatno. (2016). Peran Dunia Usaha Dan Dunia Industri Dalam Penyelenggaraan SMK Berbasis Kearifan Lokal Di Kota Mataram. Jurnal Pendidikan Vokasi, 6(2), 162-172.

Jasmini. (2019). Pembelajaran Metode Demontrasi Dan Alat Peraga Terhadap Hasil Belajar PKn Siswa Kelas III SDN 004 Teratak Buluh Kecamatan Siak Hulu. Jurnal PAJAR (Pendidikan Dan Pengajaran), 3(4), 711722.

Kamdi, W. (2017). Revitalisasi SMK: Mendongkrak Unggulan Nasional. Direktorat Pembinaan SMK Direktorat Jenderal Pendidikan Dasar Dan Menengah Kementerian Pendidikan Dan Kebudayaan, p. $1 . \quad$ Retrieved from http://psmk.kemdikbud.go.id/konten/2637/re vitalisasi-smk-mendongkrak-unggulannasional

Loyko, O., Dryga, S., Park, J., \& Palianov, M. (2015). Modern Professional Education in 
the Global Society: Comparative Study. Procedia - Social and Behavioral Sciences, 206, 464-468. https://doi.org/10.1016/j.sbspro.2015.10.084 Lutvaidah, U. (2016). Keefektifan Strategi Pembelajaran antara Metode Tutor Sebaya dengan Metode Tanya Jawab dalam Pengajaran Remidial Materi Fungsi Limit. Formatif: Jurnal Ilmiah Pendidikan MIPA, 6(3), $266-275$. https://doi.org/10.30998/formatif.v6i3.998

Nurfarhana, A., Abdillah, A., \& Prasetyono, H. (2017). Faktor Yang Berpengaruh Terhadap Disiplin Kerja Guru SMKN 1 Depok Dan SMKS Yapan Indonesia. Jurnal Research and Development Journal of Education, 44(22), 3-22.

Prananingrum, R. (2017). Persepsi Mahasiswa Tentang Penerapan Metode Cooperative Learning dan Ceramah Tanya Jawab dalam Peningkatan Minat Belajar Askeb Hamil. Jurnal Ilmiah Kesehatan, X(2), 238-241.

Prasetyono, H., Abdillah, A., Widiarto, T., \& Sriyono, H. (2018). Character-based Economic Learning Implementation and Teacher's Reinforcement on Student's Affective Competence in Minimizing Hoax. Cakrawala Pendidikan, 37(3), 426-435.

Prasetyono, Hendro, Abdillah, A., \& Fitria, D. (2018). Academic Supervision toward Teacher's Performance through Motivation as Intervening Variable. Journal of Education and Learning (EduLearn), 12(2), 188-197. https://doi.org/10.11591/edulearn.v12i2.732 4

Raden, R. A., \& Abdul, F. S. N. U. (2014). Penerapan Metode Ceramah dan Diskusi Dalam Meningkatkan Hasil Belajar PAI di SMA Negeri 44 Jakarta. Studi Al-Qur'an; Membangun Tradisi Berfikir Qur'an, 10(2), 119-131.

Saputra, S., \& Prasetyono, H. (2020). The Effect of Scientific Approach to the Activity of Learning Students in SMPN 25 Tangerang City. Jurnal PAJAR (Pendidikan Dan Pengajaran), 4(1), 20-30.
Subadi, T. (2010). Lesson Studi Berbasis PTK (Penelitian Tindakan Kelas). Surakarta: Badan Penerbit FKIP UMS.

Yibeltal, J., \& Tessega, M. (2020). Social Sciences \& Humanities Open The implementation of early childhood care and education ( ECCE ) in Bahir Dar city administration: A comparative study between private and public pre-primary schools. Social Sciences \& Humanities Open, 2(1), 100013. https://doi.org/10.1016/j.ssaho.2020.100013 